\title{
Emancipatory and critical language education: a plea for translingual possible selves and worlds
}

\section{Maria Formosinho, Paulo Jesus \& Carlos Reis}

To cite this article: Maria Formosinho, Paulo Jesus \& Carlos Reis (2016): Emancipatory and critical language education: a plea for translingual possible selves and worlds, Critical Studies in Education, DOI: 10.1080/17508487.2016.1237983

To link to this article: http://dx.doi.org/10.1080/17508487.2016.1237983

册 Published online: 30 Sep 2016.

Submit your article to this journal $\lceil\pi$

Џ Article views: 39

Q View related articles $\asymp$

View Crossmark data ¿ 


\title{
Emancipatory and critical language education: a plea for translingual possible selves and worlds
}

\author{
Maria Formosinho ${ }^{\mathrm{a}, \mathrm{b}}$, Paulo Jesus (ib ${ }^{\mathrm{b}, \mathrm{c}}$ and Carlos Reis ${ }^{\mathrm{d}}$ \\ ${ }^{a}$ CEIS 20, Coimbra University, Portugal; bUniv Portucalense, Portucalense Institute of Neuropsychology and \\ Congnitive and Behavioral Neurosciences - INPP, Oporto, Portugal; 'Universidade de Lisboa, Centro de

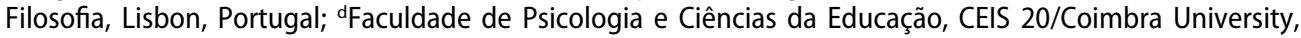 \\ Coimbra, Portugal
}

\begin{abstract}
Language is the main resource for meaningful action, including the very formation of selves and psychosocial identities, shaped by practical norms, beliefs, and values. Thus, language education constitutes one of the most powerful means for both social reproduction and social production and ideological maintenance and utopian innovation. In this paper, we attempt to emphasise the invaluable psychosocial, political, economic, and cultural function of language education in order to propose a critical view of the current transition from the monolingual to a multilingual paradigm. We maintain that multilingual approaches tend to serve the neoliberal framework and reproduce its systemic inequalities. Therefore, we argue in favour of emancipatory multilingual practices that could embody a translingual pedagogy capable of promoting the development of capabilities, the recognition of otherness, and the cultivation of diversity. Rooted in critical theory, namely in Foucault's notion of subjectification and Freire's view of conscientisation, an emancipatory translingual pedagogy would enable and empower every learner to synthesise a contextually creative field of new semantic and pragmatic relationships. Critical language education would enhance the ethos of biophilia that fosters what we term the poetics of communality and selfhood, that is to say, the proactive commitment to expanding symbolic and existential novelty.
\end{abstract}

\section{ARTICLE HISTORY}

Received 26 March 2016

Accepted

14 September 2016

\section{KEYWORDS}

Capabilities approach; emancipation; Foucault; Freire; globalisation; language education; Multilingualism; philosophy of education; Translingualism; utopia

\section{Introduction}

In this theoretical and philosophical article, we intend to translate the critical concepts proposed by contemporary thinkers, namely Ricœur, Freire, Foucault, Derrida, and Honneth, into a broad pedagogical vision in favour of personal originality, cultural innovation, and social justice. At the same time, we propose a pedagogical critique of language education, by offering a plea for translingual practices that enrich the interaction between schools, families, and communities in cross-cultural educational contexts (Canagarajah, 2013; García, Kakharia, \& Otcu, 2012; Pennycook, 2007, 2008a, 2008b). We focus specifically on language education because language is the main resource for meaningful action, including the very formation of selves and psychosocial identities, shaped by practical norms, 
beliefs, and values. Therefore, language education constitutes an ambivalent powerful means for both sociopolitical conservatism and sociopolitical change. From our part, however, we shall endorse a special kind of multilingual practice, i.e. that embodied by a translational and translingual pedagogy capable of promoting the development of selfhood, the recognition of otherness, and the cultivation of diversity. Rooted in critical theory, namely in Foucault's notion of subjectification and Freire's view of conscientisation, an emancipatory translingual pedagogy would enable and empower every learner to synthesise a contextually creative field of new semantic and social relationships. By emphasising the optimal uniqueness of every individual trajectory of multiple language acquisition and multiple language development, we value a pedagogical attitude that challenges the normative or prescriptive view of curricular organisation in which learning outcomes tend to be standardised.

The structure of our paper, organised into six sections, proposes an argument for pedagogical creativity grounded in our basic assumption that assigns intrinsic value to cultural pluralism and innovation. Hence, in the first section, we begin with a call for non-prescriptive educational attitudes, inspired by the critical philosophy and sociology of education that emphasise the importance of social production and meaningful psychosocial trajectories of action. Then, we recognise the power of language in its 'ways of worldmaking' (Goodman, 1999) and subjectification, and thereby we defend a form of dynamic and polyphonic bi/multilingualism, in keeping with the model of 'additive schooling' (Bartlett \& García, 2011) which refuses the traditional pedagogy of 'parallel monolinguism' (Heller, 2001) or the 'two solitudes' approach (Cummins, 2010). The third section is devoted to the translational and translingual practices of foreign and second language education that embody the ideal of 'capabilities development' (Nussbaum, 2000; Sen, 2011) and 'liberation' (Freire, 2000, 2001), by exploring and enhancing diverse 'pedagogies of choice' and 'transfer' (Cummins, 2009, 2015) as well as 'collaboration, inclusion and voice' (Block, 2007; Carmona \& Luschen, 2014). In the fourth section, we draw on the fluid changes undergone by 'English lingua franca' to consider the unstable, plurilithic, and expanding universe of 'global Englishes' with their 'glocal', metrolingual phenomena in the context of 'neoliberal multiculturalism' (Kubota, 2014; Kymlicka, 2013; Pennycook, 2007, 2008a, 2008b, 2009, 2010; Pennycook \& Otsuji, 2014). In view of 'neo-liberal multiculturalism', related to steady socio-economic inequalities and disregard for qualitative cultural differences, we argue, in the fifth section, invoking a postcolonial vein, that language education must take part in the 'struggle for recognition' of otherness (Honneth, 1995, 2012), and thus balance the power of languages through a 'diatopical hermeneutics' (Panikkar, 1979). The final section is intended to clarify our position on the arbitrariness of linguistic norms, and value the development of multilingual subjectivities as the most effective instrument, in the toolbox of transcultural and intercultural skills, so that one can fully engage in joint action and joint understanding (Kramsch, 2009, 2012). In closing, we recall Fromm's (1973) concept of 'biophilia' so as to equate the 'care for the diverse fullness of life' with the 'care for the diverse fullness of meaning', and meaningful glocal relationships, which entails the educational protection and stimulation of every one's creative movement within and between cultures, i.e. within and between their bodies of living symbols. 


\section{Language education: beyond normative attitudes}

This article criticises normative and prescriptive attitudes in language education, both in foreign language and mother tongue education, calling for the pedagogical awareness of the mono, bi, or multi/plural-lingual context in which it takes place. However, this criticism does not aim to fully endorse the virtues of creative anomy and functional flexibility in linguistic performances, but rather to value the process of recognition and translation (Honneth, 1995, 2012; Ricœur, 2005; Taylor et al., 1994) with regard to diverse cultural identities and diverse psychosocial trajectories. By so doing, we believe that the pedagogy of language may contribute to an emancipatory ideal that empowers one's sense of dialogical agency, ownership of peripheral culture heritage, and intercultural togetherness (with or without a sense of belonging). Indeed, the defence of counter-normativity, or rather meta-normativity, understood as the critical assessment of normative assumptions or ideological fidelities within a particular sociocultural field, seems to us to be inherent to the purport of any emancipatory pedagogy in general, and more specifically in the realm of language education. For it presents the locally situated, changing, open, purposeful, and embodied linguistic performance as the dynamic force of psychosocial processes of meaning construction and life designing, thereby opening up and expanding the range of imaginable and desirable existential possibilities. From this perspective, language education is, first and foremost, about the multiplication of one's emotional, cognitive, and active possibilities.

This focus on the axiological superiority of the possible worlds over the actual realities responds to the ontological and ethical character of educational practices that, by their very definition, unfold a process of 'becoming'. In keeping with the legacy of Enlightenment and its critical stance which remain a significant part of our historical horizon when one intends to formulate the dynamic essence of homo educandus, we value education as 'educability' (Bildsamkeit), 'formation' (Bildung), developmental force, open perfectibility, actualisation of potentialities, growth in accord with inner dispositions (Keime, Anlagen). It implies therefore a kind of merger between natural, self-organised, development, and artistic self-production, or between humans as a work of art and humans as an organic, autopoietic, teleological movement (Herbart, 1913/ 1835; Jesus, 2007; Kant, 2011, pp. 434-484). Furthermore, overcoming those naturalistic assumptions and adopting a cultural stance on Bildung as the historical self-production of mankind, our conception of homo educandus entails a specifically qualitative mode of 'becoming', one's gradual entering into symbolic interactions, one's passage from (metaphorical and literal) infancy to ever increasing articulacy, and active participation in valuable 'language games', i.e. 'the whole, consisting of language and the actions into which it is woven', (Wittgenstein, 1958, p. 5). It hence follows that language education lies at the heart of homo educandus because language acquisition and language usage are the most effective symbolic technologies capable of producing and reproducing selves and cultural life forms. The 'formation' of subjects through the 'symbolic power' of education in general, and language education in particular, unfolds the concurrent process of differential distribution and accumulation of 'symbolic capital' throughout the relational field of a given society (Bourdieu, 1984; Bourdieu \& Passeron, 1979, 1990). Whenever linguistic curricula are developed and implemented in any educational system, diverse forms of 'symbolic violence' and 'counter-violence' emerge, 
thereby unveiling the strong productive and reproductive impact of one becoming linguistically competent by complying with, resisting to, or simply ignoring the hierarchy of symbolic values assigned to different languages and different codes within every language. For the performative efficacy of language converts into the tacit production, structuration, and dissemination of social positions, identities and relationships (Bernstein, 1971-1990, 2000). Such formative linguistic power embodies what Foucault $(2001,2008,2009,2014)$ termed as 'techniques of dominion' over the self, techniques that are intimately conjoined with 'techniques of meaning making' and social government, which are locally appropriated by embodied subjects, thus becoming 'techniques of self-fashioning' and 'self-government'. Original identities, unique existential forms, innovative possibilities of cultural expression are liberated by the pedagogical creativity which transforms normative grammars into meaningful trajectories of action.

\section{Multilingual games: empowering selves and creating equity}

Though paradoxical as it may seem, the symbolic 'techniques of the self allow every individual, at once, not only to cohere with a sociocultural body of semantic and practical structures but also to transgress and innovate from within that semiotic system of shared expectations. The transgression of normative and conservative expectations in language education can be carried out through the innovative usage, synthesis, and development of symbolic and linguistic repertoires within the schooling system. By doing so, symbols and languages appear as ontologically contingent, relative, equal, and plastic 'ways of worldmaking' (Goodman, 1999). Thus, language education can encompass the 'critique of (preferred ways of) worldmaking' (Goodman, 1999, p. 94), and by the same token raise the learners' metanormative awareness regarding the intrinsic value of the multiple symbolic and linguistic possibilities of living, communicating, and understanding, though without ignoring the structural differences in their immediate value, both symbolic and material (monetisable) value.

If the main general functions of education include qualification, socialisation, and subjectification (Biesta, 2010, 2014), one must nevertheless emphasise the importance of pursuing subjectification in ways that lead to recognising and knowing oneself as a unique form of generating cultural value. Now, the manifestation of subjectification involves qualified creativity and socialised uniqueness. This means that the fulfilment of subjectification always presupposes a socially shared groundwork of symbolic and material qualities. Therefore, constructive transgression and innovation are built on the secure base of communal resources and processes. More specifically, subjectified innovation requires the developmental, socialised ability to perform powerful creative speech-acts, intentionally trained by an emancipatory language education programme, that have a transformative effect on the speakers and on their web of relationships. Those creative speech-acts may be expressed through various self-critical, self-liberating, and self-affirming ways that encompass the multifaceted powers of semantic creation in knowledge and action. That is why we shall endorse translational and translingual practices as the most adequate pedagogical method to attain 'subjectification' in the realm of language education. 
Emancipatory language education could enable and empower every learning citizen to synthesise a contextually, counter-prescriptive, counter-normative, and counterreproductive, relational field of new pragmatic relevance, new living metaphors with their creative ontological vehemence, and new stories unifying the fragmented tissue of lived experience, instead of simply valuing semantic cooperation, cohesion, and stabilisation (Kearney, 2002, 2004; Lakoff \& Johnson, 2003; Ricœur, 1992; Sperber \& Wilson, 1995). Semantic innovation and transgression become apparent, among other, through the meaningful reorganisation of interpretive structures, such as metaphor (assemblage of heterogeneous semantic materials), irony (self-distancing from one's belief or symbolic system), and storytelling (creation of life narratives through imaginative, projective, self-fiction), that play a key part in one's search for and enjoyment of new enacted utterances, the play of socially life-nurturing language games. Language education is an ambivalent process, for it comprises both social production and reproduction, the dynamics of social mobility and the statics of social stratification, the value of change and that of permanence, oriented towards a preferred, ideal, state of affairs, namely the maintenance of a societal hierarchical architecture versus the equal distribution of generative freedom.

The variety of mono-, bi-, multi-, translingual perspectives on the adequate educational policy and curricular design to enhance, enrich, overlap, embed, articulate, or balance the teaching of different languages illustrate those essential tensions. Indeed, the curricular integration of official languages, heritage languages, and other second or third foreign languages relies on political decisions that tend to be conservative, serving the welfare of the majority and the validation of their historical identity. The symbolic prestige and socio-economic use value of different languages are perceived as strongly asymmetrical, given their respectively differential positions in the local and global sociolinguistic systems. That is why the actual, demographic, multilingualism of a given politically unified area does not translate necessarily into a proportional multilingual educational system, but it rather forms a complex system of identity conflicts and competing forces (Cummins, 2000). Educational policies adopt 'mono versus multilingual' practices in the classrooms according to political decisions that concern the shaping of identities (viewed as rather monolithically cohesive or polyphonically inclusive) as well as the meaning of difference and novelty under the guise of threat, challenge, or wealth. Cosmopolitan schooling systems, open to valuing and recognising strangers, instantiate with vivid richness and intensity the continuous experience of otherness, and propose to every educator the ethical and pedagogical imperative of non-indifferent responsiveness that is ideally intrinsic to 'the community of those who have nothing in common' (Biesta, 2004, 2006; Lingis, 1994).

However, multicultural melting pots do not automatically dissolve symbolic inequalities and material asymmetries into a harmoniously resourceful multitude. Quite the opposite, in cosmopolitan cities, different languages and cultural legacies embody significant differences in power, status, and value. European languages associated with traditions of highly regarded cultural creations and socio-economic leadership, like English, French, and German, are represented by premium educational institutions (namely very selective, independent, international schools) that offer bi/multilingual programmes which develop and demand perfect bi/multilingual skills, aimed at students and families who desire to attain or retain global citizenship status, through 
mobile, distinguished, academic, and professional careers. In sharp contrast with the orthodox purism of 'additive bi/multilingualism' of prestigious schools, there are several forms of more or less symbolically violent, assimilationist, 'subtractive bilingualism' (Cummins, 2010; García, 2009; García \& Fishman, 2002; García et al., 2012; García \& Wei, 2013) embodied by most public schools, especially if located in middle class to impoverished neighbourhoods, which struggle with overall academic underachievement and learning difficulties by means of linguistic mainstreaming. These subtractive programmes serve homogenising educational goals and attempt to meet the supposed needs for sociocultural assimilation of communities where heritage languages abound and pervade their daily lives, both at home and at work, making them feel socially inferior or alien, while official languages remain mostly as foreign languages belonging to the outside privileged majority. In this case, if the enhancement of those students' linguistic proficiency in the hegemonic, official language becomes the priority goal at the expense of the recognition and mobilisation of their heritage, cultural, linguistic, and identity capital, then a 'subtractive schooling' approach (Gándara \& Hopkins, 2010; Valenzuela, 1999) is implemented which results in an overall 'subtraction' or mutilation reinforcing the asymmetry between communities and widening the divide between sameness at school and diversity in society, through a regime of 'parallel monolingualism' (Heller, 2001) or a great wall isolating the purity of 'two solitudes' (Cummins, 2010). When an official language dominates the discursive space, heritage languages are silenced and, by the same token, their communities are excluded from the formal, mainstream, schooling interactions. However, this exclusion presents itself in a variety of ways because it expresses the differential 'cultural power' of the community at stake. For instance, the German-speaking community living in Paris, Beijing, or Sao Paulo may benefit not only from their elite network of international, German-speaking, schools but also from prestigious multilingual programmes in the best public schools. In contrast, the Portuguese-speaking community in Berlin, the Ukrainian-speaking community in Lisbon, or the Pakistani-speaking community in Rome, that is to say, cultural migrant minorities with low 'symbolic power', tend to cultivate their heritage languages and celebrate their cultural rites in the margins of the schooling system, almost completely confined in their self-contained clubs, associations, and churches. When cultural capital undergoes a process of symbolic devaluation, the community of experience who lives, at least partly, on that capital will suffer from identity stigmatisation, lack of recognition, and deprivation of sociocultural agency with a strong negative impact on their social trajectories. Within the mainstream educational systems, those peripheral heritage languages tend to remain low-value symbolic assets that are not mobilised to enrich their learning experiences.

The promising, yet laborious, alternative scenario consists in promoting a 'dynamic' and polyphonic bi/multilingualism (Bartlett \& García, 2011; García, 2009; García \& Wei, 2013) that goes beyond subtractive and additive practices by developing an inclusive bi/multilingual curriculum where spontaneous and fruitful crossing over or entanglement of languages becomes the new ecology of learning, teaching, and human development as a whole. Even if no one in the teaching staff has a good command of those languages, they can be valued, promoted, and used as anchoring positions for translinguistic and transcultural dialogues, through the regular exercise of shared semantic and pragmatic 'translation' to gain experiential awareness of cultural diversity, 
and cope with the so-called boundaries of linguistic and cultural (un)translatability. As a result, instead of being oppressed, stigmatised, marginalised, or insulated, minority heritage languages may function as valuable, enriching, and fully legitimate players within the schooling language games. Moreover, all languages demonstrate the same power to supply both a secure base (for its original in-groups) and a new frontier (for its various out-groups), inviting all members of the school community to be active language learners, engaging in a non-scripted, experimental, drama to co-construct new knowledge, and enact new practical meanings. The distinction between aboriginal inand out-groups as well as the cherished native speaker entitlements undergo a profoundly transformative erosion, insofar as languages combine, interweave, and blend, thanks to audacious 'translingual practices' (Acosta, 2014; Canagarajah, 2013; García, 2009; García \& Wei, 2013; Pennycook, 2007, 2008a, 2008b, 2009, 2010).

Although it is pedagogically demanding and institutionally expensive, translingual practices open the school, the curriculum, and the classroom to permanent movement 'between and betwixt' multilingual positions, offering an extremely supportive and exploratory transitional or liminal space in which an optimal, quasi-utopian, experience of communitas and inclusive polyglossy may take place (Turner, 1967). Minor and major social positions, as well as status quo configurations, are transcended, as every learner actualise a unique way of living, knowing, and connecting within and through translingual moves. Hence, dynamic, translingual, multilingualism promotes 'critical multiculturalism' (Banks \& Banks, 2013; May \& Sleeter, 2010) because it focuses on equity and on the just redistribution of the power of agency. Just as 'langue' yields to 'parole', so too action may subdue structure; and thereby the creative impurity of grammar may feed the interpersonal and institutional processes of recognition and inclusion. On enshrining the dignity of otherness, novelty, and expressiveness, these dynamic translingual schools would incorporate the Kantian and Kohlbergian model of a 'kingdom of ends' (Korsgaard, 1996) or a 'just learning community' (Rogers, Mosley, \& Kramer, 2009). To sum up, translingual competence would provide students with the most fundamental instruments for creative and ethical life-designing, including philoxeny, responsibility for others, and joint educational scaffolding of social mobility within a world of action in which meritocracy is self-regulated by the voice of mutual care and concern for the common good.

\section{Translational and translingual praxis as the pedagogy of liberation}

The translational and translingual critique of pure grammar (or traditional grammarbased pedagogy) goes beyond the pragmatic solution of functional pedagogy focused on communication skills. For it invites one to acknowledge the contemporary experience of living in a multilingual and multicultural polyphony, whose irreducible complexity emerges as a valuable condition of cultural creativity and existential richness. The translingual critique of language education (Acosta, 2014; Canagarajah, 2013; García, 2009; García \& Wei, 2013; Pennycook, 2007, 2008a, 2008b, 2009, 2010) attempts at disclosing and disarming the ideological and power structures that produce inequality in language education, in order to liberate the possibility of a utopian polyphony. Both ideologies and utopias are always 'struggling for dominance over historical reality' (Mannheim, 1936/2002, p. 176) and always shaping the strategies of identity politics 
and their educational agenda. Linguistic and didactic ideologies tend to naturalise or essentialise a contingent, historical, state of affairs, thereby reinforcing its legitimacy, instead of unveiling the practical reasons for their investment in such 'preferred realities' in detriment of other possible worlds and languages. Linguistic utopias, on the other hand, foster the creation of more nourishing, inspirational, life forms and tend to favour the generation of communal practices through the iterative performance of symbolic bodies. Utopias welcome new possibilities as long as they are grounded in freedom, i.e. in the living instability of interlocutionary creativity with multivoiced, open, educational actions conceived as inclusive, collaborative, other-centred 'conversations' in which every voice is entitled not only to claim its irreducible uniqueness but also to enjoy its share of comforting rootedness (Carmona \& Luschen, 2014). We consider ourselves as realistic utopians in that we advocate a relational pedagogy sensitive to diverse otherness, or strangeness, mediated by grounded, pragmatic, joint ventures, and committed to virtually universal recognition, heading towards generous philoxeny in keeping with our postmodern condition of self-irony and solidarity, selfactualisation, and care for otherness, among those tied together by the liberating loss of absolute truths and all-encompassing certainties (Rorty, 1989, 1999).

The classroom can become a participatory, transformative, 'drama' of joint meaningful learning similar to the theatre of the oppressed (Boal, 1993; Freire, 2000; Ngo \& Kumashiro, 2014) in which the didactic authoritarian voice gives way to 'education as the practice of freedom' (Freire, 2001, 2013; Hooks, 1994; Morrow \& Torres, 2002), a dialogical labour of ideological critique and co-construction of desirable possible lives, worlds, and selves, through translingual consciousness, performance, and development. The current pedagogy of language education tends to conform to salient use-value criteria, thus favouring the dominance of English and European languages by upper middle-class students, despite, or because of, its uncritical focus on cosmopolitan hybridity, mobility, and fluidity, feeding the asymmetric successes of corporate globalisation. The ambivalent nature of cultural and linguistic hybridity stems from its unequal, 'privileged position' (Kubota, 2014) or, in other words, its crucial function in establishing and reinforcing the cultural capital of transnational elites in a neoliberal landscape in which language education is reduced to a competence that enhances the survival of the fittest individuals through international careers. Multilingual mobility (Martin-Jones, Blackledge, \& Crees, 2012; May, 2014) involves, therefore, a strategic commoditisation of language education and a profound blindness towards the processes of cultural and socio-economic exclusion of less instrumental languages.

As a result, language education suffers from alienation by ignoring the struggle for recognition, both in the classroom and in the social arena, from the part of heritage languages and local communities. Language education contributes, with different modes and degrees, both to the neoliberal deepening of cultural capital asymmetries, associated with social inequalities, and to the emancipation of silenced, self-effaced, or self-rejected, voices. From our standpoint, an emancipatory educational action should conjoin the liberating potential of unbounded multilingualism with the rootedness of sociocultural belonging. In practice, it would adopt a contextualised capabilities approach (Sen, 2011; Nussbaum, 2000), focused on the maximisation of opportunities to stimulate development and freedom. As successful pedagogical experiments illustrate, this can be accomplished by means of the collaborative designing of culturally 
responsive curricula (Gay, 2010), giving rise to language-rich classrooms (Himmele \& Himmele, 2009) and mutually enriching school-community exchanges (Cummins \& Early, 2011). This pedagogy of language encompasses a process of conscientisation (Freire, 2000) and multicultural recognition (Taylor et al., 1994), including the promotion of creative plurilinguism, which is not reducible to the aesthetic or ludic communication of code-switching and codemeshing (Canagarajah, 2007), and achieves a qualitative novelty comprising bi/multilingual translanguaging.

\section{Multiscales of fluidity and motion: between babel and glossolalia}

The communicational demands in a globalised world, with its increasingly wider migratory waves of people, ideas, and goods, particularly intense in Europe and North America, have defined new standards and expectations that enshrine the multi/ plural model of linguistic competences and practices. Nevertheless, one is still entitled to claim the right to use a certain language in an official manner and to assess or judge other speakers' ability and accuracy to use it, which implies the acceptance of a constitutive normativity, immanent to grammar knowledge and usage. As Jorgensen recalls (2012, p. 68), despite the rise of English as 'lingua franca' (ELF), it is expected that linguistic diversity, or even a 'superdiversity', is maintained in Europe, as multilingual practices are expected to proliferate. Also, English itself becomes a plurilithic system of performatively translational and grammatically unstable 'global Englishes' (Pennycook, 2007, 2008a, 2008b).

Against a backdrop of increasing mobility and cultural contamination, linguistic hybridity is no longer a rare and artificial event in the daily practices of many speakers who surpass the bilingual scenario and incarnate real 'metrolingualism' (Otsuji \& Pennycook, 2010, 2011). Language pedagogy must then rethink both monolingual and purely insulated or parallel multilingual prescriptivism by assimilating and participating in the new sociolinguistic realities and relationships pervaded by crossing overs. If linguistic diversity is traditionally a common phenomenon in many societies, it is true that the market-based expansion of a multidimensional process of globalisation was fuelled by an ideology that competes worldwide for the conquest of markets and pulverises territorial boundaries, once comforting for national identities and their cohesive linguistic policies. The anti-colonial and postcolonial movements have critically denounced the destructive, biocultural violence exerted by colonisers, but subtler asymmetries remain in place, now grounded in market forces and liberal canons where languages become capital and individuals are reduced to instrumental means.

Linguistic hybridity, correlative-to-language fluidity, code mixing, and systemic contamination, celebrates multiple, saturated identities that typify the experience of vulnerable individualism in 'liquid modernity' (Bauman, 2000, 2007). The 'multi/plural turn', evoked by Kubota (2014), denotes the great socio-economic and geopolitical changes of globalisation and the hegemonic forms of neoliberal ideology that promote privileged multi/plural-lingualism of an elite class. This multi/plural-lingualism derives the value of a language from its efficacy and usefulness in the global market ruled by multinational corporations. Such value assignation establishes a norm with a canon of real success, anchored in the present 'nature' of economics, which hides its historical, contextual, and contingent character. From an epistemological standpoint, such state of 
affairs require that one deepens the de Saussure (1959/1916) descriptivism that refutes the prescriptive view of grammar, and gives primacy to the study of spoken over written language. The descriptivism of modern linguistics has not obviated, however, the markedly formalistic and idealistic orientation of post-Saussurean studies, including Chomsky's Universal Grammar, against which Social Linguistics and Ethnography of Communication have rebelled, by drawing attention to the contextually embodied 'ways of speaking' and to the culturally dependent 'communicative competence' that would absorb 'linguistic competence' (Gumperz \& Hymes, 1986). If the goals of linguistics are operationalised by Chomsky through an intentional 'idealisation' of data that should make it compatible with the formalisation of a 'generative grammar', Social Linguistics returns to the empiricist tradition and creates a manifold set of sub-disciplines, like Social Dialectology, which would long remain a critical anomaly in the margins of the dominant paradigm. Confronted with the phenomena of multiculturalism in US and Canada, Fishman proposes as an autonomous programme for Sociolinguistics the task of establishing 'who speaks what language to whom and when' (Fishman, 1965). The main issues related to linguistic diversity are originally dealt by Social Linguistics which criticises the ideological discourse of linguistic purism, although it operates within a unitary conception of language, close to Saussurean structuralism. For this reason, it is legitimate and necessary to design a new epistemic framework that highlights the failure of normative and prescriptive claims, and emphasises the primacy of communication, performance, and dynamic entanglement of languages, as in translingual and metrolingual phenomena. This invites one to acknowledge the ubiquity of power relations, in the context of neoliberal multiculturalism, and respond to it with critical multiculturalism. Of course, language education is affected by and involved in these power relations that establish new forms of cultural and economic hegemony, well represented by the pervasive usage of technological instruments Globalisation, Internationalisation, Localisation and Translation (GILT)-type and the fascination with cross-cultural hybridity that transcend the logic of border demarcation.

\section{Struggle for recognition and identity in the post-monolingual condition}

The rise of national modern States transformed the schooling institutions, converted into sociopolitical tools intrinsic to the crucial process of identity and unity construction, beyond the regional particularities expressed by multiple dialects. In the disciplinary and bureaucratic logic that characterised the differentiation of modern States, the unifying ideal of a common mother tongue would produce a binding force for a community circumscribed by clearly tangible boundaries. The intimate connection established by W. von Humboldt (1999/1836) between language as energeia, or human activity, and the 'soul' (spiritual or cultural development of an individual, a nation, and mankind) epitomises, under the Romantic Weltanschauung, the constitutive tie linking one language to a unified national community. In addition, the historical, dynamic conception of language was also moulded by the Darwinian principles, the historicity of languages being understood as the evolutionary processes of adaptive living organisms in continuous and random variation. For de Saussure (1959/1916), the functioning of a linguistic system is described from a synchronic and diachronic perspective, but the singularity of every language would lie in the realm of form; though 
one might articulate the structural dimension of the system with its dynamic appropriation by empirical speakers, and therefore defend the possibility of a grammar evolution through intersubjective practical agreement. Without denoting a substantialist conception of language, assumed as 'a form rather than a substance', Saussure would postulate linguistic identity confined to the formal structure of the system, frame of reference for the speakers of a given community.

Indeed, language provides symbolic, dynamic resources for identity (de)construction, through its appropriation by the speaking subjects and social groups, demonstrating that languages do not contain fixed essences. This construction reveals the pedagogical possibility of openness, fluidity, spontaneity, relational autopoiesis, which can provoke the collapse of all solid categories of unity, identity, and continuity, such as race, gender, class, territory, or nationality. The multiple texts and voices of differentiated identity may be enacted and recreated within a collaborative workshop of joint and self-rewriting, in total opposition to the positivist and structuralist perspectives, including idealised categorisations defined by variational sociolinguistics (Callahan, 2012). The joint rewriting and recreation of identity categories, through intersubjective encounters, is nurtured by the possibility of continuous reinterpretations of utterances that interlocutors produce concurrently, responding to the shared meanings of the situation and expectations processed in situ. Even without questioning some of the sociolinguistic concepts that have discriminated within and between group variations, Callahan (2012) stresses the unpredictability of certain choices; for the effect of identity rewriting at every encounter invalidates all attempts of border demarcation. That is to say, there is no absolutely determining and overarching power in play, because every subject can, at least partly, refuse, subvert, or modify, by the very act of interlocution the 'ideology' that carries the configuring metanarrative of a specific sociolinguistic identity. Otherwise put, structure and action generate each other.

In the game of mirrors where one recognises oneself through being for and becoming with another, every self may elaborate and receive their identifying image through the concrete, material embodiment of language that inhabits them and speaks them but does not reduce them to any ways of speaking. Every self is deeper, broader, and otherwise than grammar and symbols, in the sense that to be one self is not to be a carrier of meaning but rather a synthesiser of meaning; I am an event, a poetic practice, transforming symbols and forms into actions and matters in the world. To inhabit within and through languages is to engage in the meta-normative labour of life designing, the poetics of communality and selfhood (Block, 2007). In Foucault's perspective $(2008,2009)$, the power to discipline that is exerted by the modern State tends to govern, subjugate, and normalise subjectivities, but it is self-evident that such power is conveyed by institutional forms that hold together different power mechanisms that are socially legitimate. However, as an open and ever-changing process, identity unfolds the dynamics of self/other identification, interpretation, and recognition; hence, the translingual practices transgress the stability of norms and disturb the 'normative' chaining of educational and power inequality. Translingualism (García \& Wei, 2013) is sensitive to social justice and to the development of capabilities, thus permeated by the utopian imagination that entails a double labour of critique and invention, the critical poetics of new communality and selfhood based on the interpretive questioning of lived and symbolised differences of value. 
The question of unequal identities belongs to the realm of embodied language and symbolic interactions that translate into socio-economic relationships. Thus, if the transition to a plural normativism can be understood as playing a part in postmodern deconstruction, post-structuralist criticism, and postcolonial awareness of constraining, violent, identity texts and voices, it cannot solve many tensions and contradictions. For these concerns, the refusal of universal, absolute canons to signify experience, produce selfhood, and govern human life; while at the same time, avoiding the vacuum of pure self-irony and sceptical nonsense. The normativism of absolute grounds is thereby replaced by a consciousness of incommensurability and incompleteness which requires a truly dialogical, translational, transcultural, and cross-interpretive method. Instead of 'diachronic hermeneutics', always confined within a monocultural hermeneutic circle, unable to understand a supposedly radical stranger, the transformative dialogue of self and other calls for a reciprocal displacement around the unique and communal space of giving reasons and accounts of oneself, sharing movements within and between new topoi and logoi. This is the essence of a 'diatopical hermeneutics': 'understanding the other without assuming that the other has the same basic self-understanding as I have', looking for new grammars, texts, myths, grounds, or conditions of possibility of self-intelligibility, obeying the hospitable desire of being and becoming another (Panikkar, 1979, p. 9; see also Derrida, 1998).

As Bauman (2000), Butler (2005), and Giddens (1991), among many others, have pointed out, postmodern, postnormative or postmonolingual (Gramling \& Warner, 2012; Yildiz, 2011) selfhood is a reflexive project always challenged by the social injunction of giving an intelligible account of time lived and time expected, time past and time future, actualities and potentialities, self-invention and self-discovery. Inevitably, this injunction to self-creative positioning defies the totalising and unifying purposes of Modernity, to such an extent that fragmentation means communal openness to free, boundless, and imaginative experimentation. Emblematic of reason itself that legitimises the colonisation of the other, language embodies an instance of power, because through its normativity, the coloniser produces his entitlement to affirm the hegemony of his own identity and worldview. And if the postcolonial criticism (Kubota, 2014) denounced the asymmetry of power that hides even in the hybridity and creolisation of linguistic and cultural forms, it is also clear that this hybridity supplied identity forms and transactional means for mutual recognition between coloniser and colonised. Postcolonial criticism remains, nevertheless, despite all the possible dissonances in the 'age of post-', a valuable example of mapping self/other configurations in the realm of language and power. Along these lines, Canagarajah (2013) presents translingual practices as negotiation and encounter where all interlocutors change qualitatively, adapting the norms to the context of interlocution and to the dialogical dynamics. Language has a plurivocal impact on identity construction processes, as autobiographical accounts of transcultural and translingual selves might aptly illustrate (Block, 2007). Learning a new language resignifies experience and entails a rewriting of possible selves and worlds.

\section{Plural normativism versus mono-purism in language education}

From a pedagogical point of view, the multi/plural-lingual turn in applied linguistics has fostered more holistic, ecological, diverse, perspectives in language education, as opposed to rather atomistic and segregationist, teaching models. Pedagogical 
normativism tends to pluralise itself by recognising the increasingly more common phenomena of translingual practices, reinforced by the easy access and pervasive use of information and communication technologies (Lennon, 2012). For this reason, methods and curricula of 'double or multiple monolingualism' have shifted to 'integrated bi- or multilingualism' (Jorgensen, 2012). And if it is true as Cameron (1995) states that 'Linguistic conventions are quite possibly the last repository of unquestioned authority for educated people in secular society' (as cited in Warner \& Gramling, 2013, p. 4), the fact remains that since the 70s, and under the influence of linguistic research and sociolinguistics, educators question the ideological foundations of the prescriptive discourses of the pedagogy of language. As for this normativity that permeates the pedagogical intention, Genouvrier (1972, p. 51) had already noted that 'In the past, one would have referred to dogmas. Presently, one attempts to understand them and to get rid of masks'. And he further commented:

The norm is therefore at once this set of arbitrary arguable choices, and the instrument of the cohesion of a linguistic community: it must be safeguarded as such, in this contradiction between constraint and freedom which characterises every linguistic experience. (p. 50)

Now, the naturalisation of language is no longer an epistemological issue at stake, and prescriptive purism has been assimilated to a verbal hygiene action (Cameron, 1995, 2013). The multilingual turn in second language acquisition and in foreign language education (Canagarajah, 2007) stems, not from a structural, but from a pragmatic approach, entirely consistent with the notion of multilingual competence, which provides the individual with the ability to use different formal systems and explore a wide array of relationships and selves. This means that the native speaker is not the anchoring or the reference point, as though he incarnated the orthodox canon of monolingual normativity. Cenoz and Gorter (2011) propose the diversification of learning contexts, insisting on the participation in practices that allow language learners to engage in real exchanges between their schools and their communities of origin. This multilingual competence opens up multiple fluid identities whose sense of authenticity relies on social contextualised intentions and expectations. Under the new paradigm, Levine (2014) has endorsed the replacement of a purely performative orientation in language teaching and learning assessment by a more dynamic, flexible, approach in order to consider how students develop a multilingual competence, by mobilising their own specific resources in interactive contexts of communication. In his view, the idea of cross-cultural and translingual competence refers to skills that are linguistic and extralinguistic, like intercultural skills of joint action and understanding (Kramsch, 2009, 2012; Pennycook \& Otsuji, 2014; Sung, 2014; Tupas, 2014).

\section{Conclusion}

The pedagogy of multilingual goals overlaps partly with the ideological mechanisms of powerful elite reproduction, thus recalling that cosmopolitan values derive from neoliberal, instrumental, multiculturalism (Kymlicka, 2013). Indeed, for the liberal international market, dominated by an economic elite, multilingual competence constitutes a pragmatically necessary standard. Thus, the complicity between the market and the pedagogy 
shows a strong configuration of power. The supposed liberation of global citizens goes hand in hand with the (virtually oppressive) structuration of exportable working force. This paradox of equivocal coincidence between emancipation and imposition is clearly stated by Kubota (2014, p. 2) who maintains that in bolstering neoliberal discourses, the multi/plural lose a transformative edge that seeks significant changes in the socio-political and economic conditions of people who are using, learning, and teaching language'. It is not possible to separate the process of globalisation from its own hegemonic ideological system which induces a contraction and an acceleration of shared time-space, transformed into an asymmetrical ground for togetherness and for creativity.

Liberal capitalism progresses through the continuous renewal of its own strategies, deploying a remarkable ability to assimilate and metabolise even the most threatening critique. The globalisation of markets demands the globalisation of communication and qualification whose foundations lie in language education and, more specifically, in establishing an effective lingua franca (Ricento, 2012). Higher education is especially pervious to the arrangements of political economy and its labour market constraints 'the neoliberal cascade' (Connell, 2013) which revolves around subtle gestures of neocolonial, subtractive, domination. Therefore, once faithful to biocultural diversity and to irreducibly critical multiculturalism, language education contains a most productive form of counter-hegemonic power that refuses to yield to the market laws, by empowering minority linguistic identities and inter-, transcultural encounters beyond the reduction of all cultural value to usage value. For languages as lives are ends-in-themselves, modes of being human and ways of worldmaking, whose extinction or mutilation entails an irretrievable loss in self/other-understanding. Biophilia, 'the passionate love of life and of all that is alive' (Fromm, 1973), encompasses the unconditional care for biodiversity and human biocultural diversity, including the immaterial richness of symbols and signs. Therefore, biophilia contains glossophilia, and a pedagogy that recognises the absolute, intrinsic value of languages and their creative possibilities.

\section{Disclosure statement}

No potential conflict of interest was reported by the authors.

\section{Funding}

This work was supported by the Medical Research Council: [Grant Number xxxx, xxxx].

\section{Notes on contributors}

Maria Formosinho has graduated in Philosophy (Coimbra University, Portugal), obtained a DEA in Education (Geneva University, Switzerland), a DEA in Linguistics (Paris/Sorbonne University), and a PhD in Educational Psychology (Coimbra University). She was a full professor at the Faculty of Psychology and Sciences of Education at Coimbra University. Presently, she is a senior researcher at CEIS/20 (Coimbra University) and teaches Education at Portucalense University (Porto). She has published widely in scientific journals of Education.

Paulo Jesus BA in Philosophy and Theology (Portuguese Catholic University, 1995), MA in Psychology (Coimbra University, 2000), PhD in Philosophy and Social Sciences (EHESS, Paris, 
2006), visiting scholar at NYU and Columbia (2007-2008), postdoc trainee at CREA (E. Polytechnique, Paris, 2009-2010). Currently researcher at Philosophy Center of the U. of Lisbon, Principal Investigator of the Research Project 'Poetics of Selfhood: Memory, Imagination, and Narrativity', and an assistant professor at Portucalense University (Porto, Portugal).

Carlos Reis, is currently an auxiliary professor at Coimbra University, has a $\mathrm{PhD}$ in Education Sciences, specialty in Philosophy of Education, a Master Degree in Education Sciences and a Graduation in Philosophy. He was director of the Superior School of Education, Communication and Sport, of Guarda Polytechnic Institute, where he achieved the rank of coordinator professor. Now he is an integrated member of The Coimbra's University Centre for the 20th Century Interdisciplinary Studies - CEIS20. Among other subjects, he imparted Philosophy of Education, History of Education, Epistemology and Educational Innovation in Education Sciences and Teacher Education in Graduation, Master as well as in $\mathrm{PhD}$ programmes and was supervisor of Teachers' Internships for 23 years. He has been organising international conferences and belongs to the board of several scientific journals.

\section{ORCID}

Paulo Jesus (D) http://orcid.org/0000-0002-8707-1877

\section{References}

Acosta, A. (2014). The wager of critical multilingualism studies. Critical Multilingualism Studies, 2(1), 20-37.

Banks, J., \& Banks, C. (Eds.). (2013). Multicultural education: Issues and perspectives (8th ed.). Hoboken, NJ: Wiley.

Bartlett, L., \& García, O. (2011). Additive schooling in subtractive times: Bilingual education and dominican immigrant youth in the heights. Nashville: Vanderbilt University Press.

Bauman, Z. (2000). Liquid modernity. Cambridge: Polity Press.

Bauman, Z. (2007). Liquid times: Living in an age of uncertainty. Cambridge: Polity Press.

Bernstein, B. (1971-1990). Class, codes, and control (Vol. 4). London: Routledge.

Bernstein, B. (2000). Pedagogy, symbolic control, and identity: Theory, research, critique (2nd ed.). Lanham: Rowman and Littlefield.

Biesta, G. (2004). The community of those who have nothing in common: Education and the language of responsibility. Interchange, 35(3), 307-324. doi:10.1007/BF02698880

Biesta, G. (2006). Beyond learning: Democratic education for a human future. Boulder, CO: Paradigm.

Biesta, G. (2010). Good education in an age of measurement: Ethics, politics, democracy. Boulder, CO: Paradigm.

Biesta, G. (2014). The beautiful risk of education. Boulder, CO: Paradigm.

Block, D. (2007). Second language identities. London: Continuum.

Boal, A. (1993). The theatre of the oppressed. New York, NY: Theatre Communications Group.

Bourdieu, P. (1984). Distinction: A social critique of the judgment of taste. Cambridge, MA: Harvard University Press.

Bourdieu, P., \& Passeron, J.-C. (1979). The inheritors: French students and their relations to culture. Chicago: Chicago University Press.

Bourdieu, P., \& Passeron, J.-C. (1990). Reproduction in education, society and culture. London: Sage Publications.

Butler, J. (2005). Giving an account of oneself. New York, NY: Fordham University Press.

Callahan, L. (2012). Pre-imposition vs. In situ negotiation of group and individual identities: Spanish and English in US service encounters. Critical Multilingualism Studies, 1(1), 57-73. 
Cameron, D. (1995). Verbal hygiene. London: Routledge.

Cameron, D. (2013). The one, the many and the other: Representing multi- and monolingualism in post - 9/11 verbal hygiene. Critical Multilingualism Studies, 1(2), 59-77.

Canagarajah, S. (2007). Lingua Franca English, multilingual communities, and language acquisition. The Modern Language Journal, 91(1), 923-939. doi:10.1111/modl.2007.91. issue-s1

Canagarajah, S. (2013). Translingual practice: Global Englishes and cosmopolitan relations. New York, NY: Routledge.

Carmona, J., \& Luschen, K. (Eds.). (2014). Crafting critical stories: Toward pedagogies and methodologies of collaboration, inclusion, and voice. New York, NY: Peter Lang.

Cenoz, J., \& Gorter, D. (2011). A holistic approach to multilingual education: Introduction. The Modern Language Journal, 95(3), 339-343. doi:10.1111/modl.2011.95.issue-3

Connell, R. (2013). The neoliberal cascade and education: An essay on the market agenda and its consequences. Critical Studies in Education, 54(2), 99-112.

Cummins, J. (2000). Language, power, and pedagogy: Bilingual children in the crossfire. Clevedon: Multilingual Matters.

Cummins, J. (2009). Pedagogies of choice: Challenging coercive relations of power in classrooms and communities. International Journal of Bilingual Education and Bilingualism, 12(3), 261-271. doi:10.1080/13670050903003751

Cummins, J. (2010). Teaching for transfer: Challenging the two solitudes approach in bilingual education. In J. Cummins \& N. H. Hornberger (Eds.), Encyclopedia of language and education vol. 5: Bilingual education (pp. 65-76). New York, NY: Springer.

Cummins, J. (2015). How to reverse a legacy of exclusion? Identifying high-impact educational responses. Language and Education, 29(3), 272-279. doi:10.1080/09500782.2014.994528

Cummins, J., \& Early, M. (Eds.). (2011). Identity texts: The collaborative creation of power in multilingual schools. London: Trentham Books.

de Saussure, F. (1959/1916). Course in general linguistics (Ed. by C. Bally \& A. Sechehaye). New York, NY: The Philosophical Library.

Derrida, J. (1998). Monolingualism of the other or the prosthesis of origin. Stanford, CA: Stanford University Press.

Fishman, J. (1965). Who speaks what language to whom and when. La Linguistique, 2, 67-88.

Foucault, M. (2001). Les techniques de soi. In M. Foucault (Ed.), Dits et écrits II. 1976-1988 (pp. 1602-1632). Paris: Gallimard.

Foucault, M. (2008). Le gouvernement de soi et des autres: Cours au Collège de France 1982-1983. Paris: Gallimard/Seuil.

Foucault, M. (2009). Le courage de la vérité: Le gouvernement de soi et des autres II: Cours au Collège de France 1984. Paris: Gallimard/Seuil.

Foucault, M. (2014). Subjectivité et vérité: Cours au Collège de France 1980-1981. Paris: Gallimard/Seuil.

Freire, P. (2000). The pedagogy of the oppressed (The 30th anniversary edition). New York, NY: Bloomsbury Academic.

Freire, P. (2001). Pedagogy of freedom: Ethics, democracy, and civic courage. Oxford: Rowman \& Littlefield.

Freire, P. (2013). Education for critical consciousness. London: Bloomsbury Academic.

Fromm, E. (1973). The anatomy of human destructiveness. New York, NY: Holt.

Gándara, P., \& Hopkins, M. (Eds.). (2010). Forbidden language: English learners and restrictive language policies. New York, NY: Teachers College Press.

García, O. (2009). Bilingual education in the 21st century: A global perspective. Chichester: Wiley.

García, O., \& Fishman, J. (Eds.). (2002). The multilingual apple: Languages in New York city (2nd ed.). Berlin: Mouton de Gruyter.

García, O., Kakharia, Z., \& Otcu, B. (Eds.). (2012). Bilingual community education and multilingualism: Beyond heritage languages in a global city. Bristol: Multilingual Matters.

García, O., \& Wei, L. (2013). Translanguaging: Language, bilingualism, and education. Basingstoke: Palgrave Macmillan. 
Gay, G. (2010). Culturally responsive teaching: Theory, research, and practice (2nd ed.). New York, NY: Teachers College Press.

Genouvrier, E. (1972). Quelle langue parler à l'école? Propos sur la norme du français. Langue Française, 13, 34-51. doi:10.3406/lfr.1972.5584

Giddens, A. (1991). Modernity and self-identity: Self and society in the late modern age. Cambridge, MA: Polity.

Goodman, N. (1999). Ways of worldmaking. Indianapolis: Hackett.

Gramling, D., \& Warner, C. (2012). Critical multilingualism studies: An invitation. Critical Multilingualism Studies, 1(1), 1-11.

Gumperz, J., \& Hymes, D. (Eds.). (1986). Directions in sociolinguistics: ethnography of communications. Oxford: Blackwell.

Heller, M. (2001). Undoing the macro/micro dichotomy: Ideology and categorization in a linguistic minority school. In N. Coupland, S. Srangi, \& C. Candlin (Eds.), Sociolinguistics and social theory (pp. 261-296). Harlow: Pearson.

Herbart, J. F. (1913/1835). Outlines of educational doctrine. New York, NY: MacMillan.

Himmele, P., \& Himmele, W. (2009). Language-rich classroom: A research-based framework for teaching English language learners. Alexandria, VA: ASCD.

Honneth, A. (1995). The struggle for recognition: The moral grammar of social conflicts. Cambridge, MA: Polity Press.

Honneth, A. (2012). The I in we: Studies in the theory of recognition. Cambridge, MA: Polity Press.

Hooks, B. (1994). Teaching to transgress: Education as the practice of freedom. New York, NY: Routledge.

Jesus, P. (2007). From homo educandus to homo aestheticus: Kant on education. Studi Kantiani, $19,121-130$.

Jorgensen, J. N. (2012). Ideologies and norms in language and education policies in Europe and their relationship with everyday language behaviours. Language, Culture and Curriculum, 25 (1), 57-71. doi:10.1080/07908318.2011.653058

Kant, I. (2011). Lectures on education (1803). In Anthropology, History, and Education: The Cambridge Edition of the Works of Immanuel Kant (pp. 434-484). Cambridge: Cambridge University Press.

Kearney, R. (2002). On stories. London: Routledge.

Kearney, R. (2004). The wake of imagination: Ideas of creativity in Western culture. London: Routledge.

Korsgaard, C. (1996). Creating the kingdom of ends. New York, NY: Cambridge University Press.

Kramsch, C. (2009). The multilingual subject. Oxford: Oxford University Press.

Kramsch, C. (2012). Authenticity and legitimacy in multilingual SLA. Critical Multilingualism Studies, 1(1), 107-128.

Kubota, R. (2014). The multi/plural turn, postcolonial theory, and neoliberal multiculturalism: Complicities and implications for applied linguistics. Applied Linguistics, 1-22. doi:10.1093/ applin/amu045

Kymlicka, W. (2013). Neoliberal multiculturalism? In P. A. Hall \& M. Lamont (Eds.), Social resilience in the Neo-Liberal Era (pp. 99-125). Cambridge: Cambridge University Press.

Lakoff, G., \& Johnson, M. (2003). The metaphors we live by (2nd ed.). Chicago: Chicago University Press.

Lennon, B. (2012). Can multilingualism be simulated? Critical Multilingualism Studies, 1(1), 94-106.

Levine, G. S. (2014). From performance to multilingual being in foreign language pedagogy: Lessons from L2 students abroad. Critical Multilingualism Studies, 2(1), 74-105.

Lingis, A. (1994). The community of those who have nothing in common. Bloomington: Indiana University Press.

Mannheim, K. (1936/2002). Ideology and Utopia: Collected works of Karl Mannheim (Vol. 1). London: Routledge. 
Martin-Jones, M., Blackledge, A., \& Crees, A. (Eds.). (2012). The Routledge handbook of multilingualism. New York, NY: Routledge.

May, S. (Ed.). (2014). The multilingual turn: Implications for SLA, TESOL, and bilingual education. New York, NY: Routledge.

May, S., \& Sleeter, C. (Eds.). (2010). Critical multiculturalism: Theory and praxis. New York, NY: Routledge.

Morrow, R., \& Torres, C. (2002). Reading freire and habermas: Critical pedagogy and transformative social change. New York, NY: Teachers' College Press.

Ngo, B., \& Kumashiro, K. (Eds.). (2014). Six lenses for anti-oppressive education: Partial stories, improbable conversations. New York, NY: Peter Lang.

Nussbaum, M. (2000). Women and human development: The capabilities approach. Cambridge, MA: Cambridge University Press.

Otsuji, E., \& Pennycook, A. (2010). Metrolingualism: Fixity, fluidity and language in flux. International Journal of Multilingualism, 7(3), 240-254. doi:10.1080/14790710903414331

Otsuji, E., \& Pennycook, A. (2011). Social inclusion and metrolingual practices. International Journal of Bilingual Education and Bilingualism, 14(4), 413-426. doi:10.1080/ 13670050.2011 .573065

Panikkar, R. (1979). Myth, faith and hermeneutics. New York, NY: Paulist Press.

Pennycook, A. (2007). Global Englishes and transcultural flows. London: Routledge.

Pennycook, A. (2008a). English as a language always in translation. European Journal of English Studies, 12(1), 33-47. doi:10.1080/13825570801900521

Pennycook, A. (2008b). Translingual English. Australian Review of Applied Linguistics, 31(3), 30.1-30.9. doi:10.2104/aral0830

Pennycook, A. (2009). Plurilithic Englishes: Towards a 3-D model. In K. Murata \& J. Jenkins (Eds.), Global Englishes in Asian contexts: Current and future debates (pp. 194-207). Basingstoke: Palgrave-Macmillan.

Pennycook, A. (2010). Language as a local practice. London: Routledge.

Pennycook, A., \& Otsuji, E. (2014). Market lingos and metrolingua Francas. International Multilingual Research Journal, 8(4), 255-270. doi:10.1080/19313152.2014.951907

Ricento, T. (2012). Political economy and English as a 'global' language. Critical Multilingualism Studies, 1(1), 31-56.

Ricœur, P. (1992). Oneself as another. Chicago: Chicago University Press.

Ricœur, P. (2005). The course of recognition. Cambridge, MA: Harvard University Press.

Rogers, R., Mosley, M., \& Kramer, A. (2009). Designing socially just learning communities: Critical literacy education across the lifespan. New York, NY: Routledge.

Rorty, R. (1989). Contingency, irony, and solidarity. Cambridge: Cambridge University Press.

Rorty, R. (1999). Philosophy and social hope. London: Penguin Books.

Sen, A. (2011). The idea of justice. Cambridge, MA: Harvard University Press.

Sperber, D., \& Wilson, D. (1995). Relevance: Communication and cognition (2nd ed.). Blackwell: Oxford.

Sung, C. (2014). English as a lingua franca and global identities: Perspectives from four second language learners of English in Hong Kong. Linguistics and Education, 26, 31-39. doi:10.1016/ j.linged.2014.01.010

Taylor, C., Appiah, K., Habermas, J., Rockefeller, S., Walzer, M., \& Wolf, S. (1994). Multiculturalism: Examining the politics of recognition (ed. by A. Gutmann). Princeton, NJ: Princeton University Press.

Tupas, R. (2014). Inequalities of multilingualism: Challenges to mother tongue-based multilingual education. Language and Education, 29(2), 112-124. doi:10.1080/ 09500782.2014.977295

Turner, V. (1967). Betwixt and between: The liminal period in Rites de passage. In V. Turner (Ed.), The forest of symbols: Aspects of Ndembu Ritual (pp. 93-111). Ithaca, NY: Cornell University Press.

Valenzuela, A. (1999). Subtractive schooling: US-Mexican youth and the politics of caring. Albany, NY: State of New York University Press. 
von Humboldt, W. (1999/1836). On language: On the diversity of human language construction and its influence on the mental development of the human species (Ed. by M. Losonsky). Cambridge: Cambridge University Press.

Warner, C., \& Gramling, D. (2013). Introduction to this issue. Critical Multilingualism Studies, 1 (2), 1-6.

Wittgenstein, L. (1958). Philosophical investigations (2nd ed.). Blackwell: Oxford.

Yildiz, Y. (2011). Beyond the mother tongue: The postmonolingual condition. New York, NY: Fordham University Press. 